УДК 620.92

\title{
ЕНЕРГЕТИЧНИЙ ТА ЕКОЛОГІЧНИЙ АНАЛІЗ ТЕХНОЛОГІЙ ВИРОБНИЦТВА ЕЛЕКТРОЕНЕРГІЇ 3 ТВЕРДОЇ БІОМАСИ. ЧАСТИНА 2
}

\author{
Гелетуха Г.Г., канд. техн. наук, Желсзна Т.А., канд. техн. наук, Баштовий А.І., канд. техн. наук
}

Інститут технічної теплофізики НАН Украӥни, вул. Желябова, 2а, Київ, 03680, Україна

Представлено результати енергетичного аналізу життєвого циклу виробництва електричної енергії $з$ твердої біомаси. Проведено порівняння із відповідним варіантом комбінованого виробництва теплової та електричної енергії. Розраховано баланс парникових газів протягом життєвого циклу виробництва електричної енергії 3 твердої біомаси.

Бібл. 6, табл. 4, рис. 1
Представлены результаты энергетического анализа жизненного цикла производства электрической энергии из твердой биомассы. Проведено сравнение со соответствующим вариантом комбинированного производства тепловой и электрической энергии. Рассчитан баланс парниковых газов в течение жизненного цикла производства электрической энергии из твердой биомассы.
The paper presents some results of energy analysis of the life cycle of power production from solid biomass. The results are compared with the respective case of combined heat and power production. The greenhouse gases balance during the life cycle of power production from solid biomass is calculated.

Ключові слова: біомаса, біопаливо, тверде біопаливо, теплоелектроцентраль, теплоелектростанція, життєвий цикл, парникові гази.

БМ - біомаса;

ККД - коефіцієнт корисної дії;

КТ - конденсаційна турбіна;

КТЕ - комбіноване виробництво теплової та електричної енергіï;

ПГ - парникові гази;

TEO - техніко-економічне обгрунтування;

ТЕС - теплова електростанція;

ТЕЦ - теплоелектроцентраль;

У першій частині статті було розглянуто результати енергетичного аналізу життєвого циклу комбінованого виробництва теплової та електричної енергії з твердої біомаси. У другій частині статті розглядається робота TEC, а також виконується екологічний аналіз життєвого циклу виробництва електроенергії з твердої біомаси.

\section{Оцінка енергетичної ефективності роботи ТЕС на твердій біомасі}

Відомо, що при комбінованому виробництві теплової та електричної енергї ефективність використання палива на $10 \ldots 30$ \% вище, ніж при роздільному е/е - електроенергія;

CED - показник сукупних витрат енергіï;

ced - безрозмірний показник сукупних витрат енергії;

ЕYC - коефіцієнт перетворення енергіі;

\section{Нижній індекс: \\ е - електричний; \\ т - тепловий; \\ NR - невідновлюваний.}

виробництві тієї ж кількості теплової та електричної енергії [1]. Виконаємо енергетичну оцінку роботи ТЕС на твердій біомасі (соломі та деревній трісці) за показником сукупних витрат енергії та його оберненої величини - коефіцієнту перетворення енергії [2] і порівняємо їх 3 аналогічними показниками роботи ТЕЦ. Сукупні витрати енергії визначаються протягом життєвого циклу виробництва електроенергії з біомаси, тобто від виробництва/збору біомаси до енергетичної конверсії на відповідній установці [3]. Технічні характеристики ТЕС на біомасі представлено в табл. 1.

Табл. 1. Технічні характеристики ТЕС на соломі та на деревній біомасі

\begin{tabular}{|l|c|}
\hline \multicolumn{1}{|c|}{ Параметри } & Значення \\
\hline Потужність електрична, МВт & 6 \\
\hline Період роботи, год/рік & 8000 \\
\hline Номінальне навантаження & $90 \%$ \\
\hline ККД електричний & $30 \%$ \\
\hline Витрата біопалива, т/рік & 37037 \\
\hline - солома & 51852 \\
\hline - деревна тріска & 43200 \\
\hline Виробництво електроенергії, МВт·год/рік & 6480 \\
\hline Споживання електроенергії на власні потреби, МВт·год/рік & \\
\hline
\end{tabular}


Результати оцінки показують, що при застосуванні покупної (невідновлюваної) електроенергії на власні потреби, енергетичні показники роботи ТЕС на біомасі не задовольняють навіть допустимим діапазонам значень сукупних витрат невідновлюваної енергії $\left(\operatorname{ced}_{\mathrm{NR}}<0,5\right)$ та коефіцієнту перетворення енергії $\left(\mathrm{EYC}_{\mathrm{NR}}>2\right)$. У разі ж використання частини виробленої («зеленої») електроенергії на власні потреби енергетичні показники роботи ТЕС на біомасі задовольняють вказаним допустимим діапазонам значень при відстані транспортування біомаси та вивозу золи до $100 \ldots 150$ км. При цьому показники ТЕС на деревній трісці $є$ дещо кращими, ніж ТЕС на соломі (табл. 2). Як вже зазначалося, у другому варіанті обсяг електроенергії на власні потреби не включається до показника сукупних витрат невідновлюваної енергії $\left(\mathrm{CED}_{\mathrm{NR}}\right)$, а обсяг енергії «на виході» зменшується на величину споживання електроенергії на власні потреби установки.

Табл. 2. Витрати первинної енергії протягом життєвого циклу виробництва електричної енергії з твердої біомаси

\begin{tabular}{|c|c|c|c|c|c|c|c|c|c|c|}
\hline \multirow{2}{*}{ Етап життєвого циклу } & \multicolumn{10}{|c|}{ Витрати первинної енергії, ГДж/рік } \\
\hline & \multicolumn{5}{|c|}{ ТЕЦ на соломі (I) } & \multicolumn{5}{|c|}{ ТЕЦ на деревній трісці (II) } \\
\hline 1. Споживання біомаси & \multicolumn{5}{|c|}{518518} & \multicolumn{5}{|c|}{518518} \\
\hline $\begin{array}{l}\text { 2. Попередня обробка БМ: } \\
\text { - тюкування соломи }\end{array}$ & \multicolumn{5}{|c|}{2350} & \multicolumn{5}{|c|}{-} \\
\hline - подрібнення відходів лісозаготівлі & \multicolumn{5}{|c|}{-} & \multicolumn{5}{|c|}{7618} \\
\hline $\begin{array}{l}\text { 3. Всі операції збору, } \\
\text { складування, завантаження/ } \\
\text { розвантаження, зберігання біомаси }\end{array}$ & \multicolumn{5}{|c|}{35000} & \multicolumn{5}{|c|}{21843} \\
\hline $\begin{array}{l}\text { 4. Робота ТЕЦ: } \\
\text { (4,a) е/е на власні потреби } \\
(4,6) \text { обслуговування; ремонти }\end{array}$ & \multicolumn{5}{|c|}{$\begin{array}{c}75984 \\
352\end{array}$} & \multicolumn{5}{|c|}{$\begin{array}{c}69984 \\
352\end{array}$} \\
\hline 5. Спорудження ТЕЦ & \multicolumn{5}{|c|}{946} & \multicolumn{5}{|c|}{946} \\
\hline $\begin{array}{l}\text { 6. Демонтаж, утилізація облад- } \\
\text { нання ТЕЦ }\end{array}$ & \multicolumn{5}{|c|}{118} & \multicolumn{5}{|c|}{118} \\
\hline \multirow{4}{*}{$\begin{array}{l}\text { 7. Транспортування БМ, } \\
\text { вивіз золи на місце утилізації }{ }^{1)}\end{array}$} & \multicolumn{10}{|c|}{ Відстань транспортування біопалива/золи, км } \\
\hline & \multicolumn{2}{|c|}{0} & \multicolumn{2}{|c|}{10} & \multicolumn{2}{|c|}{50} & \multicolumn{2}{|c|}{100} & \multicolumn{2}{|c|}{150} \\
\hline & I & II & I & II & I & II & I & II & I & II \\
\hline & 0 & 0 & 1913 & 2095 & 9563 & 10474 & 19126 & 20949 & 28689 & 31423 \\
\hline $\begin{array}{l}\text { CED: Енергія «на вході» } \\
\text { (сума позицій 1-7) }\end{array}$ & 633269 & 619379 & 635181 & 621474 & 642832 & 629853 & 652395 & 640327 & 661958 & 650802 \\
\hline $\begin{array}{l}\left.\text { ced }^{2}\right) \text { : Енергія «на вході» / } \\
\text { Енергія «на виході» }\end{array}$ & 5,02 & 4,68 & 5,03 & 4,70 & 5,09 & 4,76 & 5,17 & 4,84 & 5,24 & 4,92 \\
\hline $\begin{array}{l}\mathrm{EYC}^{2}=1 / \mathrm{ced}: \text { Енергія «на виході» / } \\
\text { Енергія «на вході» }\end{array}$ & 0,20 & 0,21 & 0,20 & 0,21 & 0,20 & 0,21 & 0,19 & 0,21 & 0,19 & 0,20 \\
\hline 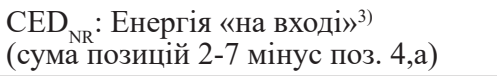 & 38767 & 30877 & 40679 & 32972 & 48330 & 41351 & 57893 & 51825 & 67456 & 62300 \\
\hline $\begin{array}{l}\operatorname{ced}_{\mathrm{NR}}^{2)} \text { : Енергія «на вході»»)/ } \\
\text { Енергія «на виході» }\end{array}$ & 0,31 & 0,23 & 0,32 & 0,25 & 0,38 & 0,31 & 0,46 & 0,39 & 0,53 & 0,47 \\
\hline $\begin{array}{l}\mathrm{EYC}_{\mathrm{NR}}{ }^{2)}=1 / \mathrm{ced}_{\mathrm{NR}} \text { : Енергія } \\
\text { «на виході»/Енергія «на вході») }\end{array}$ & 3,26 & 4,28 & 3,10 & 4,01 & 2,61 & 3,20 & 2,18 & 2,55 & 1,87 & 2,12 \\
\hline
\end{tabular}

1) Вантажопідйомність транспортного засобу по тюкованій соломі - 12,6 т, по деревній трісці - 22,4 т, по золі - 6,6 т. Вважається, що зола вивозиться на те поле, де було зібрано солому/відходи лісозаготівлі.

2) Безрозмірний показник.

3) Враховуються витрати тільки невідновлюваної енергії (тобто без споживання біопалива та «зеленої» електроенергії на власні потреби TEC).

На рис. 1 представлено порівняння коефіцієнту перетворення енергії, який враховує витрати тільки невідновлюваної енергії протягом життєвого циклу виробництва електроенергії/КТЕ, для ТЕС та ТЕЦ (КТ) на соломі та на деревній трісці. 3 даних рисунку видно, що в діапазоні відстані транспортування біомаси та вивозу золи до близько 150 км, $\mathrm{EYC}_{\mathrm{NR}}$ для ТЕЦ більш, ніж у двічі вищий, ніж для ТЕС, і знаходиться при цьому в діапазоні рекомендованих значень $\left(\mathrm{EYC}_{\mathrm{NR}}>5\right)$. Таким чином, результати енергетичного аналізу за показником сукупних витрат енергії протягом життєвого циклу технології дають додаткове обгрунтування переваг комбінованого виробництва теплової та електричної енергії $з$ біомаси над роздільним. 


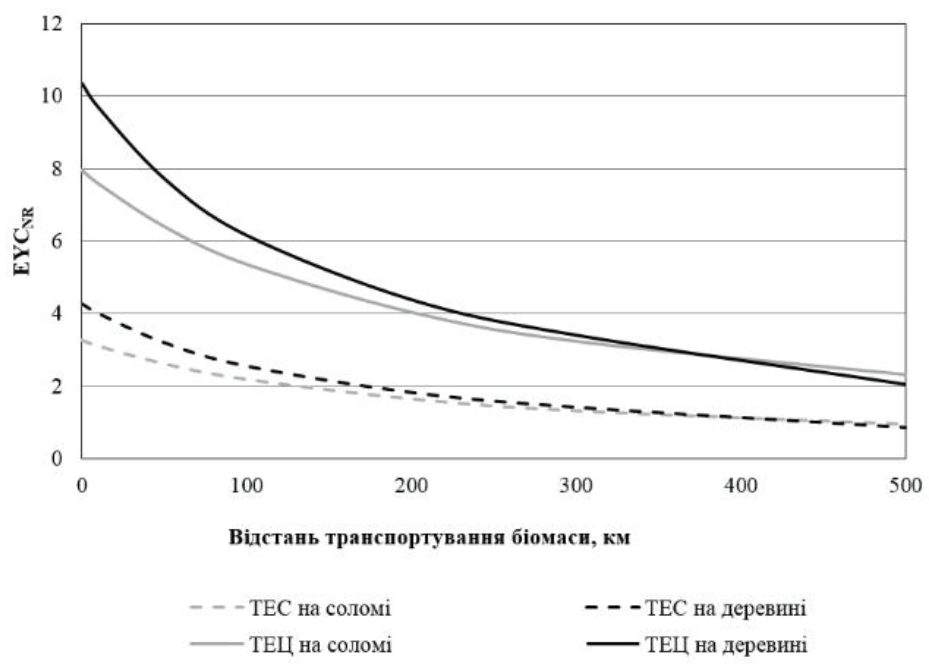

Рис. 1. Коефіцієнт перетворення енерхії для ТЕЦ (КТ) та ТЕС на твердій біомасі.

Табл. 3. Баланс діоксиду вуглецю протягом життєвого циклу виробництва електричної енергії з соломи

\begin{tabular}{|c|c|c|c|c|c|c|c|c|c|c|}
\hline \multirow{2}{*}{ Складові балансу } & \multicolumn{10}{|c|}{ Викиди $\mathrm{CO}_{2}$, т/рік } \\
\hline & \multicolumn{5}{|c|}{ ТЕЦ (КТ) $6 \mathrm{MBT}_{\mathrm{e}}+20 \mathrm{MBT}_{\mathrm{T}}(\mathrm{I})$} & \multicolumn{5}{|c|}{ TEC $6 \mathrm{MBT}_{\mathrm{e}}$ (II) } \\
\hline $\begin{array}{l}\text { 1. Використання референтного } \\
\text { викопного палива }\left(\mathrm{EC}_{\mathrm{F}}\right)^{1)}\end{array}$ & \multicolumn{5}{|c|}{23334} & \multicolumn{5}{|c|}{28927} \\
\hline 2. Тюкування соломи ${ }^{2)}$ & \multicolumn{5}{|c|}{188} & \multicolumn{5}{|c|}{157} \\
\hline $\begin{array}{l}\text { 3. Збір, складування, } \\
\text { вантаження/ розвантаження, } \\
\text { зберігання соломи }\end{array}$ & \multicolumn{5}{|c|}{1550} & \multicolumn{5}{|c|}{1295} \\
\hline \multirow{2}{*}{$\begin{array}{l}\text { 4. Транспортування соломи / } \\
\text { вивіз золи }\end{array}$} & $\mathrm{I}$ & II & $\bar{I}$ & II & $\mathrm{I}$ & II & $\bar{I}$ & II & $\mathrm{I}$ & II \\
\hline & 0 & 0 & 178 & 133 & 892 & 663 & 1785 & 1325 & 2677 & 1988 \\
\hline $\begin{array}{l}\text { Кінцеве зниження викидів СО} \\
\text { при виробництві е/е з соломи у } \\
\text { порівнянні з референтним } \\
\text { викопним паливом: } \\
\left(\mathrm{EC}_{\mathrm{F}}-\mathrm{EC}_{\mathrm{el}}\right) / \mathrm{EC}_{\mathrm{F}}^{3)}\end{array}$ & $85 \%$ & $83 \%$ & $83 \%$ & $82 \%$ & $77 \%$ & $76 \%$ & $70 \%$ & $68 \%$ & $62 \%$ & $53 \%$ \\
\hline
\end{tabular}

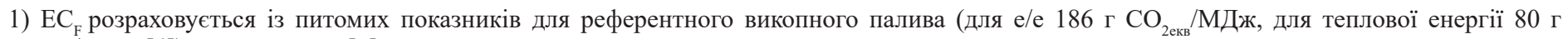
$\mathrm{CO}_{2 \text { екв }} / \mathrm{MДж} \mathrm{[4])} \mathrm{за} \mathrm{методикою} \mathrm{[5].}$

2) Питомі викиди $\mathrm{CO}_{2}$ для дизельного пального - 83,8 г $\mathrm{CO}_{2 \text { екв }}$ МДж [6].

3) $\mathrm{EC}_{\mathrm{el}}$ розраховується із Е за методикою [5]; Е - сума позицій 2-4 таблиці.

\section{Екологічна оцінка життєвого циклу виробництва електроенергї з твердої біомаси}

У даному дослідженні екологічний аналіз полягає у розрахунку балансу парникових газів протягом життєвого циклу виробництва електроенергії з твердої біомаси на ТЕЦ/ТЕС та визначенні обсягу скорочення викидів ПГ у порівнянні зі спалюванням референтного викопного палива. Розглянемо роботу ТЕЦ (КТ)/ТЕС варіант, коли частина виробленої «зеленої» електроенергії використовується на власні потреби установки. Основні операції протягом життєвого циклу, що супроводжуються викидами парникових газів (зокрема, діоксиду вуглецю), включають тюкування соломи, виробництво деревної тріски, операції збору, складування, вантаження/розвантаження та перевезення біомаси, а також вивіз золи.

Результати екологічної оцінки для обладнання на соломі представлено у табл. 3. Аналіз результатів показує, що у діапазоні відстані транспортування біопалива/золи до 100 км скорочення викидів парникових газів при виробництві електроенергії з соломи на ТЕЦ/ТЕС становить близько $70 . . .85 \%$. Це відповідає рекомендаціям Європейської Комісії щодо показників роботи біоенергетичних установок на твердій біомасі, згідно яких скорочення викидів парникових газів має становити не менше 70 \% у порівнянні з використанням референтного викопного палива [4]. Із даних таблиці також видно, що зі збільшенням відстані перевезення біопалива/золи суттєво росте внесок відповідної складової до балансу парникових газів. При відстані транспортування понад 100 км роботу ТЕЦ/ТЕС на 
соломі можна вважати неефективною 3 точки зору існуючого балансу парникових газів протягом життєвого циклу технології.

Результати екологічного аналізу для ТЕЦ/ТЕС на деревній трісці, представлені у табл. 4, є принципово схожими 3 попереднім випадком. 3 наведених даних видно, що в діапазоні відстані транспортування деревної біомаси та золи до 100 км, скорочення викидів парникових газів при виробництві електроенергії з біомаси на ТЕЦ/ТЕС становить близько $70 . .85 \%$ у порівнянні з референтним викопним паливом.

Табл. 4. Баланс діоксиду вуглецю протягом життєвого циклу виробництва електричної енергії 3 деревної тріски

\begin{tabular}{|c|c|c|c|c|c|c|c|c|c|c|}
\hline \multirow{2}{*}{ Складові балансу } & \multicolumn{10}{|c|}{ Викиди $\mathrm{CO}_{2}$, т/рік } \\
\hline & \multicolumn{5}{|c|}{ ТЕЦ (КТ) $6 \mathrm{MBT}_{\mathrm{e}}+20 \mathrm{MBT}_{\mathrm{T}}(\mathrm{I})$} & \multicolumn{5}{|c|}{ TEC $6 \mathrm{MBT}_{\mathrm{e}}(\mathrm{II})$} \\
\hline $\begin{array}{l}\text { 1. Використання референтного } \\
\text { викопного палива }\left(\mathrm{EC}_{\mathrm{F}}\right)^{1)}\end{array}$ & \multicolumn{5}{|c|}{23334} & \multicolumn{5}{|c|}{28927} \\
\hline $\begin{array}{l}\text { 2. Подрібнення відходів лісозаготівлі } \\
\text { (виробництво тріски) })^{2}\end{array}$ & \multicolumn{5}{|c|}{410} & \multicolumn{5}{|c|}{342} \\
\hline $\begin{array}{l}\text { 3. Збір, складування, } \\
\text { вантаження/ розвантаження, } \\
\text { зберігання деревного палива }\end{array}$ & \multicolumn{5}{|c|}{1119} & \multicolumn{5}{|c|}{935} \\
\hline \multirow{3}{*}{$\begin{array}{l}\text { 4. Транспортування деревної тріски / } \\
\text { вивіз золи }\end{array}$} & \multicolumn{2}{|c|}{0 км } & \multicolumn{2}{|c|}{10 км } & \multicolumn{2}{|c|}{50 км } & \multicolumn{2}{|c|}{100 км } & \multicolumn{2}{|c|}{150 км } \\
\hline & I & II & $\mathrm{I}$ & II & I & II & I & II & I & II \\
\hline & 0 & 0 & 195 & & 973 & & 1945 & & 2918 & \\
\hline $\begin{array}{l}\text { Кінцеве зниження викидів СО, } \\
\text { при виробництві е/е } 3 \text { деревної БМ у } \\
\text { порівнянні з референтним } \\
\text { викопним паливом: } \\
\left(\text { EC }_{\mathrm{F}}-\mathrm{EC}_{\mathrm{el}}\right) / \mathrm{EC}_{\mathrm{F}}^{3)}\end{array}$ & $87 \%$ & $85 \%$ & $85 \%$ & $83 \%$ & $79 \%$ & $76 \%$ & $70 \%$ & $67 \%$ & $62 \%$ & $57 \%$ \\
\hline
\end{tabular}

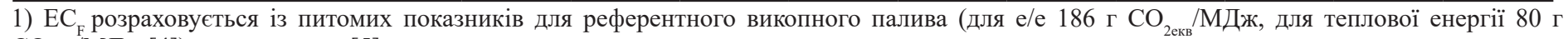
$\mathrm{CO}_{2 \text { екв }}$ МДж [4]) за методикою [5].

2) Питомі викиди $\mathrm{CO}_{2}$ для дизельного пального - 83,8 г $\mathrm{CO}_{2 е к в}$ МДж [6].

3) $\mathrm{EC}_{\mathrm{el}}$ розраховується із Е за методикою [5]; Е - сума позицій 2-4 таблиці.

\section{Висновки}

Енергетичний аналіз життєвого циклу виробництва електричної енергії 3 твердої біомаси підтверджує переваги комбінованого виробництва теплової та електричної енергії над роздільним виробництвом. В діапазоні відстані транспортування біомаси до 150 км коефіцієнт перетворення енергії ЕYC ${ }_{\mathrm{NR}}$ для ТЕЦ більш, ніж у двічі вищий, ніж для TEC, і знаходиться в діапазоні рекомендованих значень.

Результати екологічного аналізу життєвого циклу виробництва електричної енергії 3 твердої біомаси показують, що в діапазоні відстані транспортування біопалива до 100 км скорочення викидів парникових газів при виробництві електроенергії з біомаси на ТЕЦ/ TEC становить близько 70...85\% у порівнянні $з$ використанням референтного викопного палива. Це відповідає рекомендаціям Європейської Комісії щодо показників роботи біоенергетичних установок на твердій біомасі, згідно яких скорочення викидів парникових газів має становити не менше 70 \%. Із збільшенням відстані перевезення біопалива суттєво росте внесок відповідної складової до балансу викидів парникових газів. При відстані транспортування понад 100 км роботу ТЕЦ/ TEC на біомасі можна вважати неефективною 3 точки зору існуючого балансу парникових газів протягом життевого циклу технології.

Результати енергетичного та екологічного аналізу життєвого циклу виробництва теплової та/або електричної енергії з біомаси необхідно враховувати при виконанні ТЕО відповідних біоенергетичних проектів. Це допоможе у виборі найбільш ефективної технології енергетичної конверсії та визначенні оптимальної відстані транспортування біопалива.

\section{ЛІТЕРАТУРА}

1. В.Н. Клименко, А.И. Мазур, П.П. Сабашук. Когенерационные системы с тепловыми двигателями. Справочное пособие. Часть 1. Киев: ИПЦ Алкон НАН Украины, 2008, 560 стр.

2. T. Nussbaumer, M. Oser. Evaluation of biomass combustion based energy systems by cumulative energy demand and energy yield coefficient. Report for International Energy Agency and Swiss Federal Office of Energy, 2004.

3. Гелетуха Г.Г., Желєзна Т.А., Дроздова О.I. Комплексний аналіз технологій виробництва енергії 3 біомаси // Промислова теплотехніка. -2012 , т. 34, № 1 , C.87-95.

4. Commission staff working document. State of play on the sustainability of solid and gaseous biomass used for electricity, heating and cooling in the EU. Brussels, 28.7.2014, SWD(2014) 259 final

http://ec.europa.eu/energy/sites/ener/files/2014 biomass_state_of play_.pdf

5. $\overline{R e p o r t}$ from the Commission to the Council and 
the European Parliament on sustainability requirements for the use of solid and gaseous biomass sources in electricity, heating and cooling. Brussels, 25.2.2010, COM(2010)11 final

http://eur-lex.europa.eu/legal-content/EN/TXT/PDF/?u $\mathrm{ri}=\mathrm{CELEX}: 52010 \mathrm{DC} 0011 \&$ from $=\mathrm{en}$

\section{ENERGY AND ECOLOGY ANALYSIS OF TECHNOLOGIES FOR POWER PRODUCTION FROM BIOMASS. PART 2}

\section{Geletukha G.G., Zheliezna T.A., Bashtovyi A.I.}

Institute of Engineering Thermophysics of the National Academy of Sciences of Ukraine, vul. Zhelyabova, 2a, Kyiv, 03680, Ukraine

The paper presents some results of energy and ecology analysis of the life cycle of power production from solid biomass. The results confirm advantages of combine heat and power production over a separate production. Within the biomass transportation distance of up to $150 \mathrm{~km}$, the energy yield coefficient for CHP plant is more than twice as higher as that for the thermal power plant. Besides, the energy yield coefficient for CHP plant is within the recommended range of its values. The results of ecology analysis of the life cycle of power production from solid biomass show that within the biomass transportation distance of up to $100 \mathrm{~km}$, the reduction of greenhouse gases emission is about $70 \ldots 85 \%$ for CHP plant and thermal power plant. That is in line with the recommendations of the European Commission, namely that the reduction for solid biomass plants should be at least $70 \%$ as compared with the fossil fuel comparator. When the distance of biofuel transportation increases, contribution of the related component to the greenhouse gases balance considerably rises. If the transportation distance is over $100 \mathrm{~km}$, the operation of biomass CHP plant or thermal power plant can be considered inefficient from the point of view of the greenhouse gases balance during the power production life cycle. Results of energy and ecology analysis should be taken into consideration when developing technoeconomic assessment of the respective bioenergy projects.

References 6, tables 4, figure 1 .

Key words: biomass, biofuel, solid biofuel, combined heat
6. Directive 2009/28/EC on the promotion of the use of energy from renewable sources and amending and subsequently repealing Directives 2001/77/EC and 2003/30/ EC

http://eur-lex.europa.eu/legal-content/EN/TXT/ $\mathrm{PDF} /$ ?uri=CELEX:02009L0028-20151005\&from=EN

and power plant, thermal power plant, life cycle, greenhouse gases

1. V.M. Klymenko, A.I. Mazur, P.P. Sabashuk. Koheneratsiini systemy z teplovymy dvyhunamy. Dovidnyk. Chastyna 1 [Cogeneration systems with thermal engines. Reference manual. Part 1]. Kyiv: VPTS Alkon, NAN Ukrainy [Alkon, NAS of Ukraine], 2008, 560 p. (Rus.)

2. T. Nussbaumer, M. Oser. Evaluation of biomass combustion based energy systems by cumulative energy demand and energy yield coefficient. Report for International Energy Agency and Swiss Federal Office of Energy, 2004.

3. Geletukha G.G., Zheliezna T.A., Drozdova O.I. Kompleksnyi analiz tekhnolohii vyrobnytstva enerhii $\mathrm{z}$ biomasy [Complex analysis of bioenergy technologies], Promyshliennaia tieplotiekhnika [Industrial Heat Engineering], 2012, V. 34, № 1, P. 87-95. (Ukr.)

4. Commission staff working document. State of play on the sustainability of solid and gaseous biomass used for electricity, heating and cooling in the EU. Brussels, 28.7.2014, SWD(2014) 259 final

http://ec.europa.eu/energy/sites/ener/files/2014 biomass_state_of_play_pdf

5. $\bar{R}$ eport from the Commission to the Council and the European Parliament on sustainability requirements for the use of solid and gaseous biomass sources in electricity, heating and cooling. Brussels, 25.2.2010, $\mathrm{COM}(2010) 11$ final http://eur-lex.europa.eu/legal-content/EN/TXT/PDF/? uri=CELEX:52010DC0011\&from $=\mathrm{en}$

6. Directive 2009/28/EC on the promotion of the use of energy from renewable sources and amending and subsequently repealing Directives 2001/77/EC and 2003/30/ EC

http://eur-lex.europa.eu/legal-content/EN/TXT/ $\mathrm{PDF} /$ ?uri=CELEX:02009L0028-20151005\&from=EN

Получено 12.01.2017 Received 12.01.2017 